and Aleutian islands, and Japanese crested ibis, probably now extinct in the USSR. There is a sketch of each bird and its distribution, with references to further literature, several photographs, and a list of contents in English.

The introduction refers to the Soviet Union's signature in 1973-4 to four conventions: the protection of wetlands; the restriction of trade in rare species of flora and fauna which specifies many of the birds in this book, for instance the hooded crane Grus monacha; the protection of the polar bear; and a Soviet-Japanese agreement on the protection of migratory birds, covering 287 species, 30 of them under threat of extinction, as a result of which a chain of protected areas was created in the Soviet Far East.

JOHN MASSEY STEWART

The Book of Birds: five centuries of bird illustration, by A. M. Lysaght. Phaidon Press, £20.

There are some books you take a quick look at and know they will be all joy - this is one. The joys then begin to multiply, as they should with all good art, when there is a chance to live with it. Dr Lysaght is as thorough a researcher as a zoologist, with an uncanny perception of where to look for what she wants to show. And the result is a cross-section of five very productive centuries of bird drawing in considerable depth and variety. Her own comments on each separate illustration touch on art, zoology, history, religion, folklore and personal conclusion, to make each statement varied and interesting as well as highly instructive.

But only her introduction deals with the distant origins of man's portrayal of birds. No examples are reproduced. The five centuries begin with the late Middle Ages and end with the 'greats'-Gould, Wolf, Audubon-probably the richest five hundred years if that must be the set limit. Without wanting to see a single page omitted, however, I must confess to a longing for some real primitives at the beginning and some late 20th-century liveliness from the generations following Wilbur Wright; with him aerodynamics lost its mystery and the essential difference of life style between birds and land animals became suddenly understood, even by artists, who were quick to draw inspiration from the new and even more exciting field.

Dr Lysaght mentions the passing of the big bird books, the ending of the era of the shotgun naturalists and the meticulously portrayed corpse. The future, both for birds and people calls for an involvement with the living, their behavioral study and their art. Perhaps this is the right moment to suggest two more books we would like to see from the same author-just as big, just as beautiful and in just the same format. Volume I would begin with the Lascaux Caves, and Volume III with Thorburn. Meanwhile 'Volume II', it must be said again, is all joy.

KEITH SHACKLETON

\title{
British Birds of Prey, by Leslie Brown. Collins, New Naturalist, $£ 6$.
}

Leslie Brown, whose experience of African birds of prey is unrivalled, here reveals a deep knowledge of the life histories of British birds of prey and the problems that face them. He begins with an explanation of anatomical functions such as visual acuity, wing slots etc. in relation to their way of life, and a review of their status in Britain and their classification. The next fifteen chapters, dealing with individual species, are some of the best in the book: in a succinct and very readable, almost conversational, style he describes the birds' appearance and status, what is known from ringing about their migrations, and their displays, nesting behaviour and nesting success, all in considerable detail. These life histories are remarkable surveys of the published literature and valuable too in their emphasis on the gaps in our knowledge and the failure of ornithologists to record or publish data. 
In the last six chapters he reviews the probable changes in the habitat and status of raptors over the last 3000 years: foods, breeding habits, the problems they have to cope with - often the result of some beastliness by man-and finally conservation. He points out that only in the so-called developed countries does the dislike of raptors degenerate into a systematic campaign of eradication, 'and nowhere do the narrow sectional interests arrogate to themselves to break the law more than in Britain'. Furthermore, the reports of this type of law-breaking more often than not involve gamekeepers employed by some 'very eminent persons indeed'. He emphasises the need for better law enforcement and for public observation hides at the most commonly robbed eagle and kite nests. Finally there are two invaluable appendices, summarising the mass of information on food and what is known about breeding biology.

Apart from a few minor contradictions, this is an excellent and valuable book, with 40 black and white photographs and a number of explicit line drawings by Heinzel.

PETER CONDER

Monkeys without Tails, by John Napier. BBC, $£ 5.25$.

This expanded and updated version of the author's Royal Institution Lectures for young people, televised by the BBC in $1970 / 71$, is a lively and interesting account of the basic principles of evolution with special emphasis on two of the tail-less 'monkeys', the chimpanzee and man.

Professor Napier sets the scene by taking the reader on an imaginary tour of a Primate Zoo, from which we learn that there are 186 different species and about 523 subspecies or races. This is followed by a chapter on evolutionary principles such as variation and natural selection. Illustrating natural selection in action in a behavioural context, there is an interesting account of the potato-washing and wheat-washing activities of the Japanese macaque monkeys of Koshima, which will surely please those who believe that evolution proceeds through females and not males, for in these monkeys the new habits were introduced by a juvenile female and spread to its mother and other females in the group; the adult males do not take any part and 'appear to form a conservative cadre sitting on the sidelines bristling with disapproval at the permissiveness of the females and the younger generation.'

Perhaps the most valuable part of the book is the section on the evolution of the mammals and the emergence of the primates-surprisingly early, although they then showed none of the arboreal characters by which we recognise the order today. In discussing the differences between the gorilla and present-day chimpanzees Professor Napier follows the Dutch zoologist Adriaan Kortlandt in believing that the chimpanzee's aggressive behaviour when faced with predators like leopards, their use of natural objects as tools and their two-footed walk are possibly the result of living in the past in more open savanna country, until the coming of early man, with his clubs and spears, forced them into the forest where they are now found.

The book is well illustrated in colour and black-and-white, and the authoritative text is leavened with wit.

JOHN CLEGG

\section{Jungle Journeys in Ceylon, by Iris Darnton. Galaxy Books, Lavenham, Suffolk, $£ 4.80$.}

When I first went out to Ceylon, the people of the hinterland were some of the most delightful one could hope to meet, living at a speed which must have changed little since Biblical times, their villages set in idyllic surroundings amidst the forests and hills. Iris Darnton describes these lovely places, especially the village tanks around which the life of the village is centred, although she does not give any intimate description of the people's daily lives and beliefs; but the language problem makes it difficult to break down their natural shyness. Tropical jungles are profound places, 